BNL-25211

\title{
SELECTION AND EVALUATION OF MATERIALS FOR ADVANCED WATER ELECTROLYZERS
}

\section{S. Srinivasan, P.W.T. Lu, G. Kissel, F. Kulesa and J. Orehotsky}

\author{
Department of Energy and Environment \\ Brookhaven National Laboratory \\ Upton, N.Y. 11973
}

\section{INTRODUCTION}

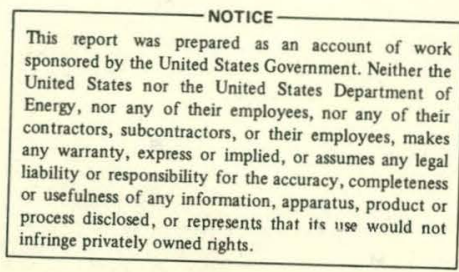

This report was prepared as an account of work sponsored by the United States Government. Neither the Energy, nor any of their employees, nor any of their contractors, subcontractors, or their employees, makes liability or respons or implied, or assumes any legal processuness of any information, apparatus, product or infringe privately owned rights.

Efforts are underway in several American and European laboratories to develop advanced electrolyzers which decompose water at high current densities (> $500 \mathrm{~mA} \mathrm{~cm}{ }^{-2}$ ) and at cell potentials close to thermo-neutral potential. Basically, two approaches are being pursued to reach these goals solid polymer electrolyte water electrolysis and alkaline water electrolysis at temperatures of $120^{\circ} \mathrm{C}$ or higher. The activities at BNL during the last year have consisted mainly of investigations on anode electrocatalysts for solid polymer electrolyte water electrolyzers and on cell components for alkaline water electrolyzers operating at $120^{\circ} \mathrm{C}$.

\section{ANODE ELECTROCATALYSTS FOR SOLID POLYMER ELECTROLYTE WATER ELECTROLYZERS}

\section{Electrochemical and Ellipsometric Studies on Ruthenium}

Due to the highly acidic environment in the General Electric Solid Polymer Electrolyte (SPE) Water Electrolyzer, it is necessary to use noble metal based electrocatalysts for both the hydrogen and oxygen evolution reactions. Iridium is one of the best electrocatalysts for the oxygen evolution reaction but is far too expensive to be used in the GE SPE electrolyzer. Ruthenium is about 10 times less expensive than iridium and shows an initial electrocatalytic activity nearly as high as iridium. However, there are problems connected with its dissolution at anodic potentials and the significant loss in electrocatalytic activity with time. In order to develop ruthenium based catalysts, it is essential to elucidate the mechanisms of these processes and the regions of potential in which the metal or oxide is stable. The results of the electrochemical and ellipsometric methods, used for such investigations, may be summarized as follows:

1. Optical analyses of ruthenium anodes reveal formation of $\mathrm{Ru}(\mathrm{OH})_{3}$ films at 0.73 volt versus the potential of the reversible hydrogen electrode (RHE). The $\mathrm{Ru}(\mathrm{OH})_{3} \mathrm{film}$ is further oxidized to $\mathrm{RuO}_{2} \cdot \mathrm{YH}_{2} \mathrm{O}$ at potentials above $0.94 \mathrm{~V} / \mathrm{RHE}$.

2. The ellipsometric studies confirm that oxide films formed anodically can be reduced cathodically. 


\section{DISCLAIMER}

This report was prepared as an account of work sponsored by an agency of the United States Government. Neither the United States Government nor any agency Thereof, nor any of their employees, makes any warranty, express or implied, or assumes any legal liability or responsibility for the accuracy, completeness, or usefulness of any information, apparatus, product, or process disclosed, or represents that its use would not infringe privately owned rights. Reference herein to any specific commercial product, process, or service by trade name, trademark, manufacturer, or otherwise does not necessarily constitute or imply its endorsement, recommendation, or favoring by the United States Government or any agency thereof. The views and opinions of authors expressed herein do not necessarily state or reflect those of the United States Government or any agency thereof. 


\section{DISCLAIMER}

Portions of this document may be illegible in electronic image products. Images are produced from the best available original document. 
3. The critical potential at which ruthenium corrodes rapidly in 258 trifluoromethane sulfonic acid is 1.45 volts/RHE.

4. The performance degradation for oxygen evolution on $\mathrm{RuO}_{x}$ catalyst is presumably due to the gradual accumulation of $\mathrm{RuO}_{2} \mathrm{film}$ on the surface of RuO particles by a dissolutionprecipitation process (Figure 1).

Ruthenium Based Mixed Oxides

With the main aim of stabilizing ruthenium based anodes for SPE water electrolyzers, studies were commenced on mixed oxides of ruthenium with other metals. The essential criteria to be satisfied by the mixed oxides are:

1. High"electrocatalytic activity for the oxygen evolution reaction;

2. Same crystal structure and comparable unit cell size of two components to form solid solutions;

3. High electronic conductivity;

4. Formation of intermediate binary phase oxide in which Ru cations exist with a valence lower than its normal quadrivalent state; and

5. Corrosion resistance in the TFMSA environment.

Mixed oxides of ruthenium with $\mathrm{Pb}, \mathrm{Mn}$ or $\mathrm{Sr}$ were prepared by the thermal decomposition method on a titanium substrate and were examined as oxygen evolution electrocatalysts. The most promising system with respect to electrocatalytic activity and minimal time variation of overpotential is the $\mathrm{Ru}-\mathrm{Mn}$ mixed oxide. The mixed oxides of $\mathrm{Ru}$ with $\mathrm{Sr}$ or $\mathrm{Pb}$ were unstable.

CELL COMPONENTS FOR ADVANCED ALKALINE WATER ELECTROLYZERS

\section{Separators}

Over 50 organic and inorganic materials (porous, non-woven, polypropylene felts, ion exchange membranes, concretes, zeolites, etc.) have been tested as candidates for separators, first at below $100^{\circ} \mathrm{C}$ and the more promising ones up to $160^{\circ} \mathrm{C}$. Only a small number of materials are suitable for separators in alkaline water electrolyzers operating at above $100^{\circ} \mathrm{C}$. Nafion and potassium titanate are the most promising as confirmed by long term evaluation (over 5000 hours) under water electrolysis operating conditions. 
Anode and Cathode Electrocatalysts

The performance of nickel cobalt oxide anodes and nickel boride cathodes were determined in single cells operating at $120^{\circ}$ and $150^{\circ} \mathrm{C}$ for periods over two thousand hours. The improvement in performance over nickel electrodes is very significant both from the point of view of higher electrocatalytic activity and minimal time variation of overpotential. Sintered nickel, impregnated with nickel hydroxide also shows promise as an oxygen evolution electrocatalyst.

Gaskets, Seals, Cell Frames

The materials, screened for fabrication of cell containers, were polyanylether, polysulfone, Tefzel and polypropylene. Polysulfone proved to be the best. 'retion or Teflon-lined materials appear most satisfactory for seals in water electrolysis cells operating at temperatures in the region $100-150^{\circ} \mathrm{C}$.

CONCLUSIONS AND FUTURE WORK

The mechanism of dissolution of ruthenium anodes and of the time variation of overpotential on such electrodes have been elucidated using combined electrochemical-ellipsometric studies. Attempts are being made to stabilize ruthenium based electrocatalysts for SPE water electrolyrers by investigation of mixed oxides will the requisite characteristics for highly efficient oxygen electrodes.

The following materials have been identified as the most attractive for advanced alkaline water electrolyzers operating at $120-150^{\circ} \mathrm{C}$.

Anode Electrocatalyst - High Surface Area Nickel Cobalt Oxide.

Cathode Electrocatalyst - High Surface Area Nickel Boride.

Separator - Teflon Bonded Potassium Titanate or Nafion.

Cell Frame - Teflon or Teflon Based.

The tests on barrier materials, electrodes and cell components have so far been carried out on a static basis in a pressure vessel. Teledyne Energy Systems (TES) has designed and fabricated an advanced alkaline water electrolysis test rig (5-cell stack). In a joint BNL-TES-University of Virginia program, the most promising materials will be tested for performance and/or life in this test-rig. 


\section{ACKNOWLEDGEMENTS}

This work was carried out under the auspices of the United States Department of Energy. John Orehotsky is on the faculty in the Engineering Department at Wilkes College, Wilkes-Barre, PA. and spent the summer of 1978 at BNL as a Visiting scientist. The authors are grateful to Drs. J. McBreen and W. E. O'Grady for helpful discussions and suggestions.

MECHANISM OF PERFORMANCE DEGRADATION WITH TIME FOR OXYGEN EVOLUTION ON RUOX ELECTRODES IN SPE WATER ELECTROLYZERS

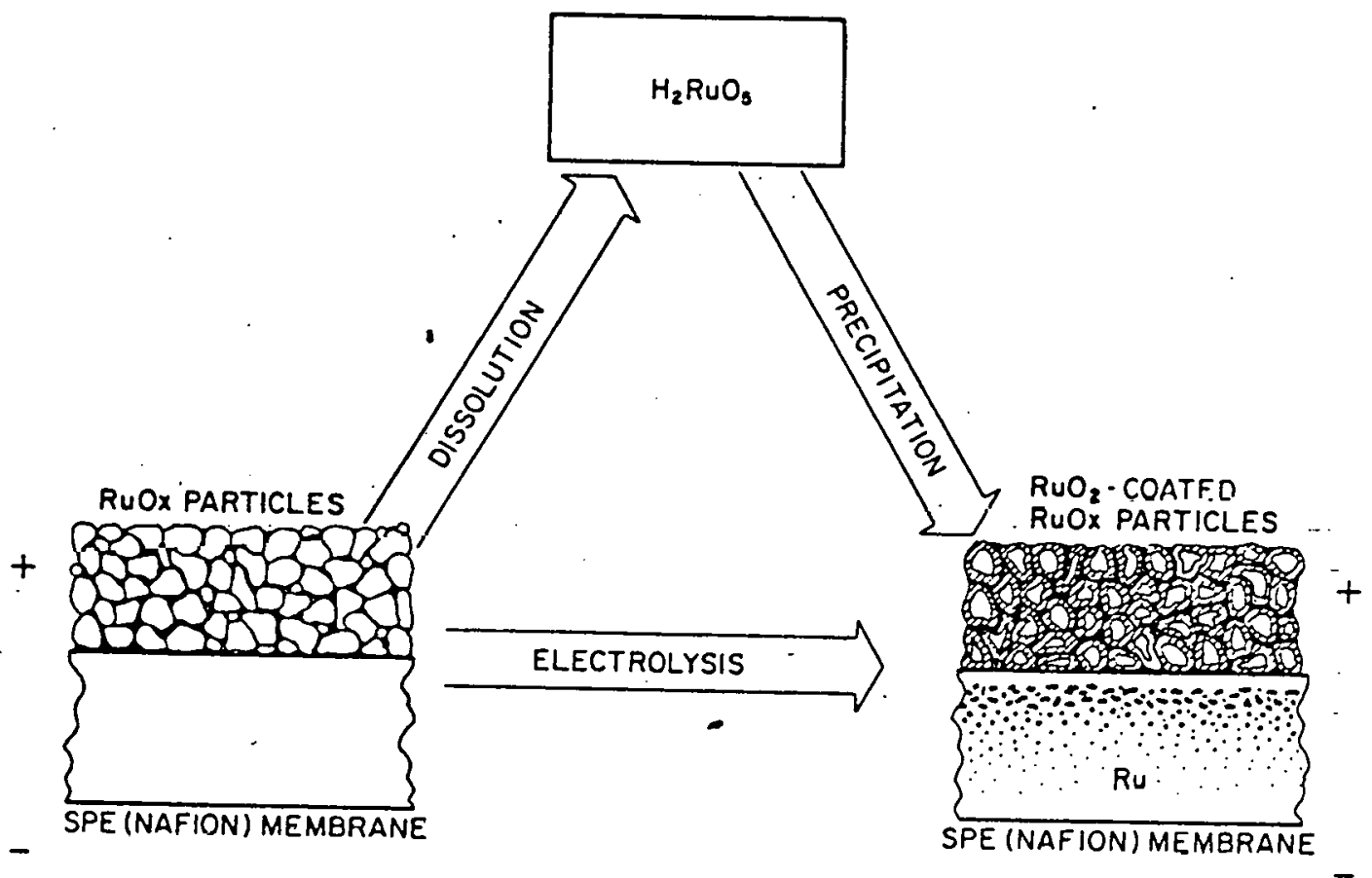

Figure 1. Proposed mechanism of performance degradation with time for oxygen evolution on $\mathrm{RuO}_{x}$ electrodes in SPE water electrolyzers. 